pure and applied science is illusory as is the concept of a border between long term basic research and short term commercial research. Given the shifting mosaic of scientific development, influenced as it must be by external forces of society, he nevertheless argued that there has been in the past a tendency to "put too much pressure" on the academics. He asked that there should be high priority for modernization of the pattern of higher education, and that the universities should produce biological engineers in recognition of the increasing importance of biology in the modern world. "The last war was a physies war", but, if things had gone differently, biology could have been the dominant influence. Education and the need for a reform of it seems to have featured in most of the speeches, which have not been published in full by the Fabian Society. Mr John Maddox, emphasizing the unpredictability of scientific development, also asked for a radical reform of tertiary education-the dropping of A-levels as university requirements, more general undergraduate courses with vocational and specialized training postponed to the postgraduate stage. To make the govern. ment machine for supporting science function more efficiently, he also asked for a reorganization of the research councils, so as to make them more clearly responsible for identifiable tasks.

But does industry want generalists? One minority view among participants was that industrialists are in practice more interested in reducing the time and money spent in job-training among new recruits, but most were agreed that quality matters more than specialization. This led into considerations of how far it was up to the education system to deal with the specific needs of industry, and how far scientists themselves were "objective-orientated", and Dr Walter Marshall gave it as his opinion that there has recently been a change of interest among those leaving the universities. What was agreed as urgent was to involve social considerations in technological decisions, to counteract the unpredictability of science by trying to foresee the consequences of what is already known.

Discussion in the session on industry and technology tended to be sceptical about the extent of Government involvement in industrial affairs. Once the basic economic directions have been laid down, the feeling was that it is better to let industry get on with the job-Sir Frank Kearton spoke of time-wasting and a general vagueness introduced by continual consultations and committee meetings about details. Bodies with specific aims, such as the Industrial Reorganization Corporation, have had greater success, but this seems to have been because of the way they were run and offers no strong argument for increasing their number.

Discussion of manpower and personal motivation seems to have stimulated more speculation from the contributors. To some extent, this overlapped with earlier discussions of education, but on the question of the individual's motivation several disturbing points were raised and others narrowly avoided. Professor Marie Jahoda, for example, mentioned changes in attitudes to work since the war, but, on the assumption that basic motivations are the same both in the Government and on the shop floor, left it to the Government to interpret its policies in terms meaningful at the other end of the hierarchy. Nothing was said about the difference between having the job one wants at the top, and having little choice at the bottom: it might not be easy to convince a roadsweeper of the purpose for life inherent in his career, but a role of this kind was actually suggested for education. Mr W. E. J. McCarthy, on the other hand, emphasized the divergence of aims between management and manpower, and the consequent unresolved difficulties.

\section{HEALTH SERVICE Costs of Disease}

UNTIL last November, the Ministries of Health and Social Security were quite independent, so it is hardly surprising that the first annual report (HMSO, $£ 2$ ) of the new Department of Health and Social Security, formed by amalgamation of the two ministries, reads as if the Stationery Office has by accident bound two separate reports under one cover. Descriptions of the measures the Government and the Civil Service have taken to coordinate the two ministries in more than name are being saved for the report of the department's first full year.

During the financial year 1967-68, expenditure on health and welfare services reached $£ 1,490$ million, about a ninth of all public expenditure by central government and local authorities. In the financial year just finished, it is estimated that the cost of these services will be $£ 1,614$ million. During 1968, the number of principals providing a full general practice service increased by 121 to 19,970 ; the steady decline in the number of GPs-in the three years up to October 1966 the number in practice dropped by 505-seems to have been halted, but only just in time. And the average number of patients per doctor also rose marginally by five, to 2,477. The General Practice Finance Corporation which began lending in May 1967 has been doing brisk business with its loans for financing practice premises-by March 1968, 320 loans worth $£ 1,570,000$ had been approved. Improvement grants from the executive councils, another way in which doctors can finance improvements of their surgeries, amounted to $£ 139,000$ during the year.

The reintroduction of prescription charges on June 10,1968 , had an interesting effect on the volume and cost of prescriptions. The number of prescriptions fell by 8 per cent compared with the second six months of 1967, but the average ingredient cost per prescription rose in 1968 by 8 per cent to $8 s 1 d$. These changes no doubt reflect the decisions of patients to buy their own aspirins and common household remedies instead of bothering the Health Service for them, but at the same time it looks as if doctors may be prescribing some preparations in larger quantities, particularly to patients not entitled to exemption from charges. The ministry claims, however, that the net effect of reintroducing charges has been a decrease in the rate of increase of cost to the health service of pharmaceuticals; during the second half of 1968 , the total cost of drugs prescribed was only 0.6 per cent more than in the same period in 1967, whereas in the second half of 1967 drug costs were 7-8 per cent up on the same period in 1966 .

Local authority health services cost $£ 216 \cdot 2$ million in 1967-68 and are estimated at $£ 238 \cdot 4$ million in 1968-69. The national measles vaccination campaign launched in May 1968 had a marked effect on incidence of the 
disease; in the last quarter of 1966 there were 135,000 notified cases, but only 37,000 in the last quarter of 1968. A survey of another childhood disease, mumps, is to be arranged. Fluoridation of water is still meeting opposition as strong as it is unfounded; only 2 million people in England and Wales receive fluoridated water.

For the first time since 1962, there was a slight decrease in the size of the waiting list for hospital treatment but, despite the more than $\mathfrak{£} 90$ million spent on hospitals, the number of beds decreased from 27,091 to 26,846 . Building schemes valued at $£ 124$ million were started in 1967-68, compared with $£ 108$ million in the previous year. Although the total number of nursing staff increased by $3,132(1 \cdot 2$ per cent), the number of full time staff decreased by $0 \cdot 2$ per cent. The report says that the fall in the number of 18 year olds in the population accounts for the fall in the number of pupil nurses and with no understatement concludes "that efforts to recruit and retain nursing staff will have to be maintained".

\section{PESTICIDES}

\section{Swings and Roundabouts}

The New York Academy of Sciences has at last published the proceedings of the symposium held in May 1967 (Ann. NY Acad. Sci., 160, 1-422; 1969). Although it is now far from up to date, the symposium should be compulsory reading for students of pollution by pesticides, if only because it provides a comprehensive review of essential background information. The eight sections range from discussion of the general ecological aspects of pollution to the biochemistry, pharmacology and physiology of pesticides. Many of the classic picces of work on the subject are described, including the tale of the consequences of controlling gnats at Clear Lake, California-now an object lesson in pesticide problems.

In September 1949, under strictly controlled conditions, Clear Lake was treated with an analogue of DDT, called DDD, at a concentration of one part in 70 million. Biologists were persuaded that at this concentration the gnats would be destroyed but the fish and birds would be unharmed. For two years, no gnat larvae were found in the lake, but by September 1954, a second dose, this time at a concentration of one part in 50 million, was needed and three years later a third dose at the same concentration was applied. It was not until 1960, however, that western grebes were found dying of tremors characteristic of poisoning by chlorinated hydrocarbons. The grebes contained up to 1,600 parts per million of DDD. Moreover, there was a notable decline in the nesting population of grebes and the fish on which they fed contained even higher concentrations of DDD.

Not everyone may be concerned at the fate of the grebes, but the symposium describes an example of ecological disturbance with a direct effect on man's health. In the Demerara River estuary in what was then British Guiana, DDT was used in the forties to eradicate the mosquito Anopheles darlingi. By 1948, this vector of malaria had been eliminated, the agricultural economy of the area had been changed and mechanized crop farming had replaced animal farming. As a result $A$. aquasalis, which had previously fed on cattle, began to feed off man and started to transmit malaria. During 1961-62, just ten years after the successful programme against $A$. darlingi and malaria had finished, 93 cases of vivax malaria occurred in the delta.

\section{ENVIRONMENT}

\section{Lovers of the Land Unife}

Is the world heading for an environmental crisis if pollution continues unchecked? Professor Barry Commoner of Washington University, St Louis, has thought for some time that this will happen. He argued his case again at the conference last week in London on "The Future of Man's Environment", organized by the Soil Association. He cited examples of modern technology-nuclear reactors, artificial fertilizers, gasoline engines and pesticides-which have "stretched the web of the ecosystem". But he said there is hope of making "technology conform to the powerful constraints of the living environment". In the United States, one particularly optimistic sign of public concern about pollution is the formation in the past six months of student environmental groups.

Professor Commoner's audience of about 100 representatives of British societies and organizations concerned with the environment hardly needed persuading about the dangers of pollution. Their object, indeed, was to discuss ways of coordinating their work more effectively, and they were greatly encouraged by Professor Commoner's emphasis on the importance of voluntary bodies working together cooperatively.

There was therefore some surprise when it was learnt that such a body is already being planned by the standing committee of "The Countryside in 1970" conference. This committee has set up a voluntary bodies working party under the chairmanship of Lord Molson, chairman of the Council for the Preservation of Rural England, and Sir Landsborough Thomson, president of the Council for Nature, with the object of forming a "National Coordinating Committee for Environmental Conservation".

But will this committee embrace a sufficiently wide range of interests, and will it be effective enough? Several at the meeting raised these questions, and the Soil Association will organize another conference to see how things are going in about six months time. One obviously relevant consideration is that the European Conservation Year is only a few months away, and time should not be lost if advantage is to be taken of the current interest of European governments in tackling environmental problems.

If a coordinated body on environmental conservation is to be a successful pressure group it must have access to scientific information. Professor Commoner argued that one of the first steps should be the publication of a journal. Part of the difficulty in assessing the dangers of pollution is that too little is known. The Soil Association is helping in this direction in a small way through research on its farmland at Haughley near Stowmarket in Suffolk. There, the association is in the fortunate position of being able to compare farmland that has been managed without the use of chemical sprays and artificial fertilizers for many years with similar farmland which has received fertilizers and 